\title{
Amir Attaran
}

Armed with facts and a flair for the dramatic, Amir Attaran is a master at bringing global health agencies to task-even when his views make enemies out of friends.

On a rainy summer day, Amir Attaran navigates a friend's borrowed station wagon through the wet streets of Ottawa on his way to pick up his girlfriend from a doctor's appointment.

After kissing her hello, Attaran picks up right where he left off: railing against what he calls the "foreign aid industrial complex," the network of global agencies and donor programs that are his current obsession.

"My latest kick has been to try to make this foreign aid establishment accountable," says Attaran. "The public health advocacy movement has only matured to the point where we talk about needing more money, and I'm sorry, but that's not good enough, no matter what Jeff Sachs and Bob Geldof and Bono say."

This declaration neatly wraps up Attaran's temperament-a combination of the scientist's belief in the power of truth, the showman's flair for a public spectacle and the lawyer's drive to argue down anyone who disputes the evidence. At the tender age of 39, Attaran has already taken on some of the most hallowed institutions in global health, including the US Agency for International Development (USAID), the World Health Organization (WHO), the World Bank, and even the Nobel Peace Prize-winning nonprofit group Médecins Sans Frontières (MSF).

Attaran is merciless in his critiques and completely willing to switch sides when the evidence demands it. This has occasionally made enemies of former friends, earning Attaran some infamy in the public health community. But it has also gained him respect for spurring fast action from bureaucratic agencies that are difficult to budge. "He's a likeable rascal; he has learned that public discomfort is often a motivator to get things done," says Chris Hentschel, chief executive officer of the Geneva-based nonprofit Medicines for Malaria Venture.

Attaran lobbed his latest grenade in April, accusing the World Bank of underfunding its malaria program and lying about the project's success in Brazil and India (Lancet 368, 247-252; 2006). The World Bank quickly rebutted the allegations, but the damage was done. Prominent media outlets covered the story, and ignited a fierce debate in the blogosphere.

This approach has served Attaran well.

In 2004, Attaran accused the WHO and the Global Fund to Fight AIDS, Tuberculosis and Malaria of medical malpractice for not adequately supporting poor countries' use of the newer artemisinin-based treatments for malaria (Lancet 363, 237-240; 2004). Later that year, the Global Fund modified its policies to require use of the more effective drugs.

That year, Attaran also alleged that USAID was wasting money and blocking attempts to find out how funds are spent in its malaria program (Nature 430, 932-933; 2004). The article resulted in a Senate hearing and, later, in changes to USAID's policies.

Attaran's mode of public confrontation goes back to his student days. A triple citizen of Iran, Canada and the US, he studied neurobiology at the University of California at Berkeley. He then spent six miserable months working on a doctoral degree at the
California Institute of Technology before decamping for Oxford University, where he became embroiled in a fight with the university in 1993.

Oxford had lost its license for disposal of radioactive waste, and was advising researchers to dump it down the drain or toss it in the garbage. When Attaran called an official to object to the policy, he says the official told him to "mind his place" and added, "Sometimes life is hard, even at Oxford University," before slamming down the phone.

That inspired Attaran, who remembers thinking, "OK, mate, I'll show you how hard life is going to be." He called a reporter at the Guardian newspaper who exposed the episode in a series of articles. Attaran's life was more difficult after the incident, but he managed to leave Oxford with a $\mathrm{PhD}$ in 1995.

That same year, Attaran headed for law school and argued environmental law cases for the Sierra Legal Defense Fund. He also worked for consumer advocate and frequent presidential candidate Ralph Nader. It was in Nader's office that Attaran first studied malaria — and learned the tactics of guerilla advocacy. But he soon broke with his environmentalist colleagues while negotiating the international treaty on Persistent Organic Pollutants, which aimed to ban DDT along with 11 other chemicals.

Attaran disagreed with the DDT ban, saying it would leave poor countries vulnerable to malaria (see "DDT returns" page 870) and began a successful campaign to incorporate his position into the treaty. That victory took him toward his calling: public health advocacy. "I realized then that I had just achieved something that would save a lot more lives than I might have as a scientist," he says.

Attaran's next move was to work with MSF to try and force drug companies to drop prices for the poor. MSF officials had thought that intellectual property laws were blocking access to AIDS medicines in poor countries. But after studying the issue, Attaran concluded that patents were not the problem (JAMA 286, 1886-1892; 2001).

His controversial stance earned him enemies among MSF and its allies, including Jamie Love, a patent activist who had also worked with Nader. "You really think patents don't raise prices?" Love wrote in one email to Attaran. "Are you a bona fide moron or something?" Attaran countered that by ignoring the truth, MSF was wasting precious resources.

Convinced that nothing more could be done without more money, Attaran went to Cambridge to join forces with the economist Jeffrey Sachs, who has pushed rich countries to fork over more foreign aid.

But Attaran quickly grew weary of what seemed like complacency and hypocrisy in the donor community.

"I think it's heartbreaking when you see people in the foreign aid establishment travel on a business class ticket to another country, check into a four-star hotel, and go to a conference on how to help the poor," he says. "I've done it enough, so I'm culpable."

Now a Canada Research Chair at the University of Ottawa, Attaran's mission is to hold aid agencies, donors and their contractors accountable for what they spend. His concern isn't just a gadfly's desire to stir up trouble. He argues that politicians will stop giving money if it's not clear that aid

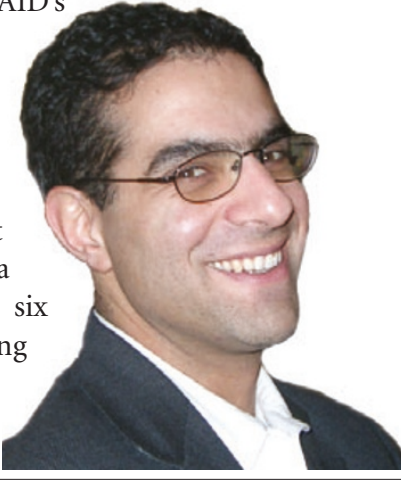

"We talk about needing more money, and I'm sorry, but that's not good enough, no matter what Jeff Sachs and Bob Geldof and Bono say." programs are working.

That concern is what motivates his rants against Bono on rainy afternoons and his attacks on the World Bank in the pages of prestigious journals. "You have to go after them with honesty," he says. "It's the right thing to do."

Erika Check, Ottawa 